\title{
Uji Organoleptik Sari Jagung Di Laboratorium Kimia FMIPA UNP
}

\author{
Iswendi*), Eka Yusmaita, Annisa Dewi Pangestuti \\ Pendidikan Kimia/ Kimia/ FMIPA/ Universitas Negeri Padang \\ *)Iswendi, $\equiv$ iswendi@fmipa.unp.ac.id
}

Revisi 18/07/2019;

Diterima 23/08/2019;

Publish 05/09/2019

Kata kunci:

laboratorium, sari jagung, uji organoleptik

\begin{abstract}
Abstrak
Uji organoleptik berkaitan tentang penerimaan suka atau tidak suka panelis terhadap produk makanan yang dihasilkan. Uji organoleptik ini dilakukan pada minuman sari jagung. Minuman yang telah diproduksi merupakan minuman olahan bulir jagung yang diproses secara filtrasi kemudian minuman tersebut dikemas dengan label ATOMS yang merupakan kependekan dari "Ayo Teman Ojolali Minum Susu". Penelitian ini dilakukan pada 20 orang panelis yang dipilih secara acak. Aspek yang diujikan pada penelitian ini adalah tingkat kesukaan rasa, aroma, warna, dan tekstur sari jagung. Panelis yang dipilih adalah mahasiswa kimia yang telah melakukan praktikum di laboratorium kimia FMIPA UNP, dengan asumsi seluruh panelis dalam kondisi sehat dan bukanlah ahli di bidang makanan. Penelitian ini dianalisis menggunakan teknik skoring. Skoring penilaian produk, yaitu tidak suka (dengan nilai 1), netral (dengan nilai 2), agak suka (dengan nilai 3), suka (dengan nilai 4) dan sangat suka (dengan nilai 5). Perolehan hasil uji organoleptik pada aspek aroma rerata nilainya 4,05; warna 4,20; tekstur 4,15; rasa 4,30; tingkat kemanisan; 4,15 dan tingkat kekentalan 3,85. Berdasarkan rerata ini disimpulkan bahwa uji organoleptik sari jagung oleh panelis berada pada level suka.
\end{abstract}

This is an open access article distributed under the Creative Commons Attribution License, which permits unrestricted use,

\section{PENDAHULUAN}

\section{Analisis Situasi}

Jagung merupakan salah satu komoditas pertanian yang memiliki prospek besar untuk dikembangkan namun belum dimanfaatkan secara maksimal. Pemanfaatan Jagung masih sangat terbatas, khususnya di kota Padang. Hal ini disebabkan belum banyaknya produk olahan yang berbahan dasar Jagung di pasaran. Biasanya jagung dinikmati dalam bentuk jagung rebus dan pergedel jagung. Padahal jagung ini memiliki potensi yang besar untuk dijadikan makanan olahan lainnya. Ditambah lagi karena saat ini trend pemanfaatan jagung telah bergeser dari makanan pokok kearah pemanfaatannya menjadi makanan olahan. 


\section{Suluah Bendang: Jurnal Ilmiah Pengabdian Kepada Masyarakat}

Vol.19, No.2, 2019

Iswendi, Eka Yusmaita

Jagung memiliki kandungan antioksidan yang tinggi. Antioksidan ini berfungsi sebagai antihipertensi, pencegahan gangguan fungsi hati, jantung koroner, mencegah terjadinya penuaan dini. Jagung juga dapat dimanfaatkan sebagai pengobatan (terapi) untuk otot dan tulang, mencegah gigi berlubang, mencegah kanker, dan penyakit jantung. Minyak jagung bermanfaat menurunkan kolesterol, berat badan, memelihara kesehatan otak, sistem syaraf, memperlancar pengeluaran empedu, menetralisir hati, meringankan infeksi dan batu dikandung empedu, meringankan penyakit radang hati, membantu menghentikan pendarahan (mimisan dan batuk berdarah), mencegah penyakit kulit kasar, dan mencegah penyakit penyempitan pembuluh darah (Suwarno, 2010).

Di Indonesia, jagung dijadikan makanan pokok kedua setelah padi. Jagung di konsumsi dengan berbagai macam cara. Jagung yang masih muda, salah satunya jenis jagung manis yang paling disukai orang, biasanya di konsumsi oleh masyarakat dalam olahan seperti jagung rebus atau jagung bakar, dan selain itu masyarakat juga mengolahnya dalam bentuk tepung jagung atau tepung maizena dan minyak jagung (Ikawati, 2013).

Susu adalah minuman yang kaya gizi dan sangat bagus dikonsumsi oleh segala usia. Susu yang biasanya sering dikonsumsi banyak jenisnya, seperti susu segar, susu instan, atau susu kental manis, Semua jenis susu ini selain tinggi kandungan proteinnya juga kaya akan kandungan karbohidrat. Bagi penderita diabetes, mereka tidak cocok minum susu, maka dicari alternatif lain, sehingga para penderita dapat tercukupi kebutuhannya akan susu, akan tetapi tidak akan berpengaruh buruk terhadap mereka. Salah satu solusinya adalah dengan minum susu nabati olahan jagung. Jagung kaya akan protein, akan tetapi rendah akan kadar gulanya sehingga cocok di buat susu nabati, selain itu susu nabati juga tidak bau amis seperti susu hewani. Susu nabati dapat memulihkan energi dengan cepat dan menjaga kesehatan mata, hati, lambung, dan usus. Selain itu susu ini bebas kolesterol karena berasal dari tumbuhan, serta cocok untuk penyakit diabetes karena mengandung gula alami (Widyatmiko, 2008).

Salah satu komoditas industri pangan dengan bahan baku biji jagung yang dianggap cukup potensial untuk dikembangkan adalah susu. Susu merupakan jenis minuman kesehatan yang dibuat dari biji buah jagung (Zea mays) muda/manis, direbus dan dikeringkan (Jacobs, 1980). Konsumsi susu di Indonesia masih rendah, padahal susu memiliki banyak manfaat. Salah satu alasan orang tidak mengonsumsi susu adalah karena intoleransi laktosa (tidak tahan terhadap gula susu atau laktosa), dimana lambung tidak bisa mencerna gula susu (Muhajir, Rahim, \& Hutomo, 2014). Protein dalam susu jagung/sari jagung mempunyai komposisi asam amino yang cukup baik (Harianja, Rusmalin, \& Yusraini, 2015) sehingga baik dikonsumsi oleh seseorang yang alergi terhadap protein susu sapi.

Kelebihan susu jagung dibandingkan dengan susu sapi adalah bahan bakunya mudah didapat dengan harga tidak terlalu tinggi. Jagung tidak mengandung laktat. Susu jagung mengandung serat lebih banyak, cocok buat mereka yang diet

Susu jagung/sari jagung diperoleh dengan cara penggilingan biji jagung yang sebelumnya telah di rebus di dalam air, Kemudian hasil dari penggilingan disaring untuk mendapatkan filtratnya. Kandungan ekstrak karbohidrat dalam susu jagung dipengaruhi oleh varietas jagung, jumlah air yang ditambahkan, jangka waktu dan kondisi penyimpanan, kehalusan gilingan, dan perlakuan panas. Selain jagung manis, bahan utama pembuatan susu jagung adalah gula pasir, CMC dan air (Ikawati, 2013).

\section{Solusi dan Target}

Untuk mengetahui kualitas dari suatu produk makanan, maka dilakukan pengujian, salah satu bentuk pengujian pada makanan adalah uji organoleptik. Uji organoleptik atau uji indera atau uji sensor merupakan cara pengujian dengan menggunakan indera manusia sebagai alat utama untuk pengukuran daya penerimaan terhadap produk (Nifah, 2015). 
Panelis yang dipilih adalah panelis tidak ahli, yaitu mahasiswa kimia yang telah melakukan praktikum di laboratorium kimia FMIPA UNP, dengan asumsi seluruh panelis dalam kondisi sehat dan bukanlah ahli di bidang makanan. Penelitian ini dianalisis menggunakan teknik skoring. Skoring penilaian produk, yaitu tidak suka (dengan nilai 1), netral (dengan nilai 2), agak suka (dengan nilai 3), suka (dengan nilai 4) dan sangat suka (dengan nilai 5).

\section{METODE PELAKSANAAN}

\section{Tempat dan Waktu}

Penelitian ini dilakukan di Laboratorium Kimia FMIPA UNP.

\section{Khalayak Sasaran}

Subjek penelitian ini adalah mahasiswa kimia yang dipilih secara acak mata kuliah biokimia.

\section{Metode Pengabdian}

Jenis penelitian ini merupakan penelitian kualitatif, dengan metode survey. Pendekatan kualitatif disini dimaksudkan untuk mengungkapkan sebuah fakta empiris secara objektif dengan berlandaskan pada logika keilmuan (Arikunto, 2010). Survey yang dilakukan mengukur sikap subjektif konsumen terhadap produk berdasarkan sifat - sifat dari produk, seperti warna, aroma, tekstur, rasa, tingkat keasaman, dan tingkat kekentalan (Nifah, 2015). Hasil yang diperoleh adalah tingkat kesukaan terhadap produk. Konsumen yang dipilih adalah panelis semi terlatih, dimana panelis ini diminta untuk mencicipi minuman sari jagung kemudian mengisi angket tentang sifat sensorik dari produk tersebut.Jagung yang digunakan pada penelitian ini merupakan jagung manis (Zae mays saccharata) yang mengandung gula lebih banyak daripada pati. Jagung manis ini di dapatkan dari perkebunan jagung Lubuk Alung, Padang Pariaman.

\section{Proses Pembuatan Susu Jagung}

\section{Alat}

Adapun alat yang digunakan dalam penelitian ini adalah mixer, freezer, panci, blander, timbangan, saringan, kompor, baskom, sendok pengaduk, pisau, gelas ukur $100 \mathrm{~mL}$ dan termometer,

\section{Bahan}

Bahan yang digunakan jagung manis, air, gula pasir, vanile, dan garam.

\section{Proses}

Adapun proses pembuatan susu jagung adalah sebagai berikut:

1. Pengupasan

Jagung manis dikupas dengan cara membuang kulit jagung serta rambut yang menempel pada biji jagung.

2. Pencucian

Jagung manis yang telah dikupas dicuci dengan air bersih untuk menghilangkan kotoran yang masih melekat.

3. Pemipilan

Jagung manis yang telah direbus selanjutnya dipipil. Pemipilan dimaksudkan untuk melepaskan biji jagung dari tongkolnya. Pemipilan dilakukan dengan menguunakan pisau sampai diperoleh biji jagung manis.

4. Penghalusan

Biji jagung selanjutnya dihaluskan dengan menggunakan blender. Biji jagung dibelender hingga halus dengan menambahkan air yang sebelumnya telah dihangatkan terlebih dahulu. Dengan perbandingan air dan jagung 4:1. Dari jagung yang dihaluskan diperoleh bubur jagung.

5. Penyaringan 
Bubur jagung yang dihasilkan kemudian disaring menggunakan kain saring. Filtrat yang dihasilkan merupakan susu jagung mentah.

6. Pasteurisasi

Selanjutnya, susu dipanaskan dan diukur suhunya dengan termometer. Pemanasan dihentikan jika sudah mencapai suhu $70^{\circ} \mathrm{C}$ agar protein jagung tidak terdenaturasi, kemudian didinginkan dan disimpan.

\section{Indikator Keberhasilan}

Terdapat dua indikator keberhasilan pada penelitian ini, yang pertama adalah minuman sari jagung yang dihasilkan homogen (tidak menggumpal). Indikator yang kedua adalah perolehan skor uji organoleptik dari respon panelis berada pada level suka.

\section{Metode Evaluasi}

Hasil penelitian ini memberikan informasi tentang proses pembuatan susu jagung, sampai meminta tanggapan kepada panelis sebanyak 20 orang melalui lembar angket tentang uji kesukaan aroma, tekstur, rasa dan warna minuman sari jagung.

\section{HASIL DAN PEMBAHASAN}

Uji organoleptik merupakan pengujian secara efektif, dimana pengujian ini dilakukan untuk mengukur sikap subjektif konsumen terhadap produk berdasarkan sifat - sifat dari produk, seperti warna, aroma, tekstur, rasa, tingkat keasaman, dan tingkat kekentalan. Hasil yang diperoleh adalah tingkat kesukaan terhadap produk.

Pengujian organoleptik dilakukan oleh panelis semi terlatih yang terdiri dari mahasiswa Kimia Universitas Negeri Padang yang mengambil mata kuliah Biokimia sebanyak 20 orang. Parameter yang dinilai yaitu aroma, warna, tekstur, rasa,tingkat kemanisan dan tingkat kekentalan. Pada penilaian ini memiliki beberapa tingkat kesukaan dengan nilai tertentu, yaitu tidak suka (dengan nilai 1), Netral (dengan nilai 2), Agak suka (dengan nilai 3), Suka (dengan nilai 4) dan sangat suka (dengan nilai 5).Hasil dari pengujian organoleptik dapat dilihat dari tabel berikut:

Tabel 1. Rekapitulasi data uji Organoleptik sari jagung

\begin{tabular}{|c|c|c|c|c|c|c|}
\hline \multirow{2}{*}{ Panelis } & \multicolumn{6}{|c|}{ Variable } \\
\cline { 2 - 7 } & Aroma & Warna & Tekstur & Rasa & $\begin{array}{c}\text { Tingkat } \\
\text { Kemanisan }\end{array}$ & $\begin{array}{c}\text { Tingkat } \\
\text { Kekentalan }\end{array}$ \\
\hline 1 & 4 & 4 & 3 & 5 & 5 & 5 \\
\hline 2 & 4 & 4 & 3 & 3 & 3 & 3 \\
\hline 3 & 4 & 4 & 4 & 5 & 5 & 4 \\
\hline 4 & 4 & 4 & 4 & 5 & 5 & 4 \\
\hline 5 & 4 & 5 & 5 & 5 & 4 & 5 \\
\hline 6 & 5 & 2 & 4 & 5 & 2 & 3 \\
\hline 7 & 4 & 5 & 5 & 4 & 4 & 2 \\
\hline 8 & 3 & 2 & 4 & 3 & 3 & 4 \\
\hline 9 & 5 & 4 & 4 & 4 & 4 & 5 \\
\hline 10 & 4 & 5 & 4 & 4 & 5 & 4 \\
\hline 11 & 4 & 5 & 4 & 4 & 4 & 3 \\
\hline 12 & 4 & 5 & 4 & 4 & 3 & 4 \\
\hline 13 & 4 & 4 & 4 & 4 & 4 & 4 \\
\hline
\end{tabular}




\begin{tabular}{|c|c|c|c|c|c|c|}
\hline 14 & 5 & 4 & 4 & 4 & 5 & 3 \\
\hline 15 & 4 & 4 & 5 & 5 & 5 & 5 \\
\hline 16 & 4 & 5 & 4 & 4 & 4 & 5 \\
\hline 17 & 5 & 4 & 4 & 5 & 5 & 4 \\
\hline 18 & 5 & 5 & 4 & 5 & 4 & 2 \\
\hline 19 & 1 & 4 & 5 & 5 & 5 & 5 \\
\hline 20 & 4 & 5 & 5 & 3 & 4 & 3 \\
\hline Jumlah & 81 & 84 & 83 & 86 & 83 & 77 \\
\hline Rerata & 4,05 & 4,20 & 4,15 & 4,30 & 4,15 & 3,85 \\
\hline
\end{tabular}

\section{Aroma}

Dalam industri pangan pengujian aroma dan bau dianggap sebagai yang paling penting dari semua pengujian, dimana aroma atau bau dengan cepat memberikan hasil penilaian terhadap produk terkait, baik diterima atau tidaknya suatu produk. Timbulnya suatu aroma dan bau dari suatu produk disebabkan karena zat bau tersebut bersifat volatile ( mudah menguap), sedikit larut air dan lemak (Prabandari, 2011).

Hasil uji organoleptik aroma sari jagung oleh panelis berbeda - beda, yaitu aroma yang sangat disukai, suka, agak suka, netral, dan tidak suka. Berikut data hasil uji organoleptik pada aroma sari jagung :

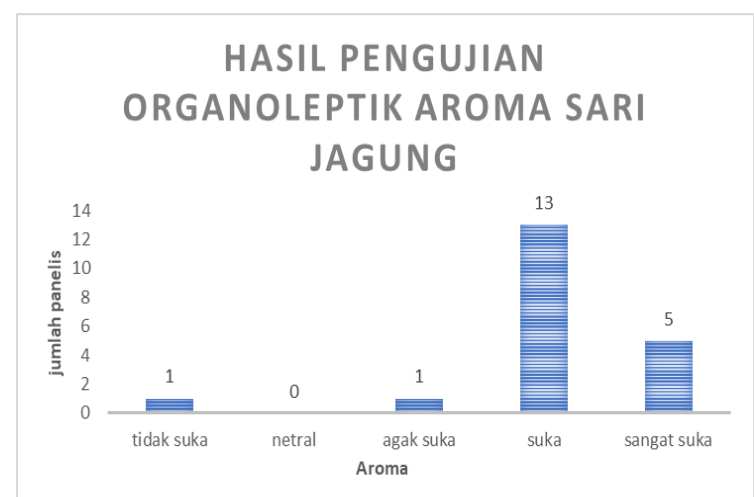

Grafik 1. Hasil data uji organoleptik dari aroma sari jagung.

Dari data dapat di ketahui bahwa pada sari jagung ini mayoritas aromanya disukai oleh panelis dengan rerata 4,05. Menurut Susilorini (2006), aroma merupakan Flavor yang menunjukan bau sedap atau enak (Susilorini, 2006).

\section{Warna}

Warna merupakan sifat bahan yang berasal dari penyebaran spektrum sinar, begitu juga dengan kilap dari bahan yang dipengaruhi oleh sinar pantul. Warna bukan merupakan suatu zat, melainkan sensasi sensoris karena adanya ransangan dari seberkas energi radiasi yang jatuh ke indra penglihatan. Warna juga merupakan atribut kualitas yang paling penting, bersamaan dengan tekstur, dan rasa, warna juga berperan dalam menentukan tingkat penerimaan suatu bahan pangan. Secara visual faktor warna tampil lebih dahulu dan kadang -kadang sangat menentukan suatu bahan yang dinilai bergizi, enak, dan teksturnya sangat baik tidak akan diterima apabila memiliki warna yang tidak sedap dipandang atau memberi kesan telah menyimpang dari warna yang seharusnya (Prabandari, 2011). 
Hasil dari uji organoleptik warna sari jagung oleh panelis berbeda - beda, yaitu warna yang sangat disukai, suka, agak suka, netral, dan tidak suka, berikut adalah data hasil pengujian organoleptik pada warna sari jagung:

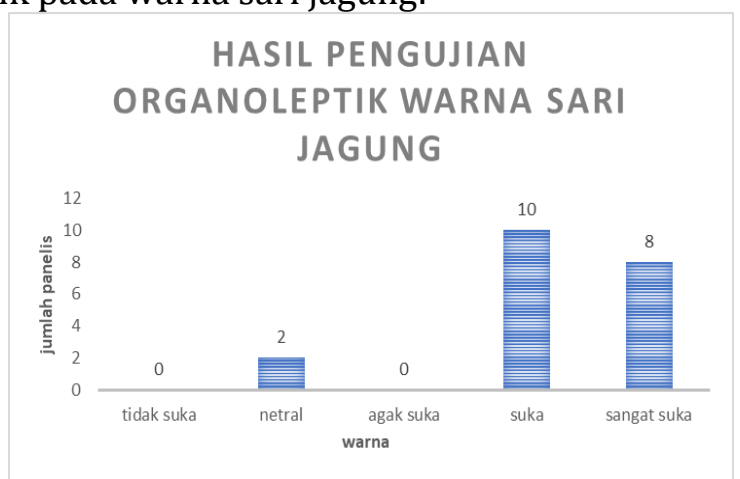

Grafik 2. Hasil data uji organoleptik dari warna sari jagung.

Dari hasil pengujian didapatkan bahwa warna yang dihasilkan dari sari jagung disukai oleh panelis dengan rerata 4,20. Warna yang di dapat adalah warna sari jagung yang agak kekuningan, warna ini dihasilkan dari warna kuning jagung yang berasal dari pigmen warna betakaroten dan zeaxhantin yang memiliki warna kuning. Menurut (Iskandar, 2011), Jagung mengandung zat warna betakaroten, jagung manis yang kekuning-kuningan karena adanya pigmen pada jagung tersebut yang dikenal dengan zeaxhantin (Suarni \& Widowati, 2005).

\section{Tekstur}

Hasil uji organoleptik tekstur sari jagung oleh panelis berbed-beda, yaitu tekstur yang sangat disukai, suka, agak suka, netral, dan tidak suka. berikut adalah data hasil pengujian organoleptik pada tekstur sari jagung:

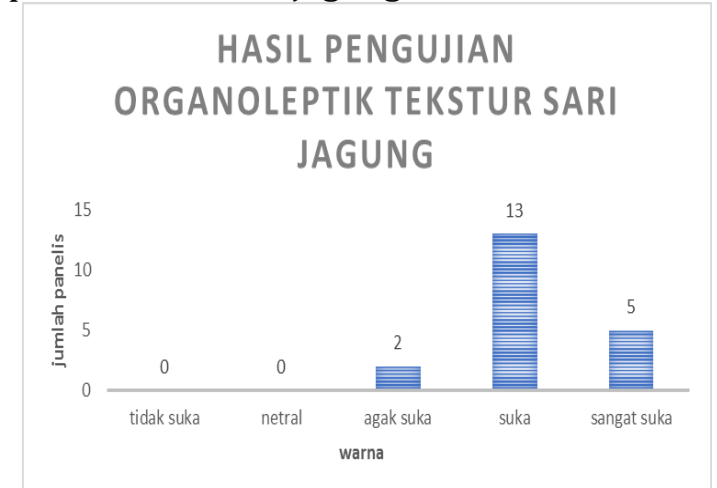

Grafik 3. Hasil data uji organoleptik dari tekstur sari jagung.

Pada sari jagung ini mayoritas teksturnya disukai oleh panelis dengan rerata 4,15.

Rasa

Flavour atau rasa didefinisikan sebagai ransangan yang di timbulkan oleh bahan yang di makan, yang dirasakan oleh indra pengecap atau pembau, serta ransangan lainnya seperti perabaan dan penerimaan derajat panas oleh mulut. Parameter rasa berperan dalam menentukan tingkan penerimaan darisuatu bahan pangan oleh konsumennya (Prabandari, 2011).

Hasil uji organoleptik rasa sari jagung oleh panelis berbeda-beda, yaitu rasa yang sangat disukai, suka, agak suka, netral, dan tidak suka. 


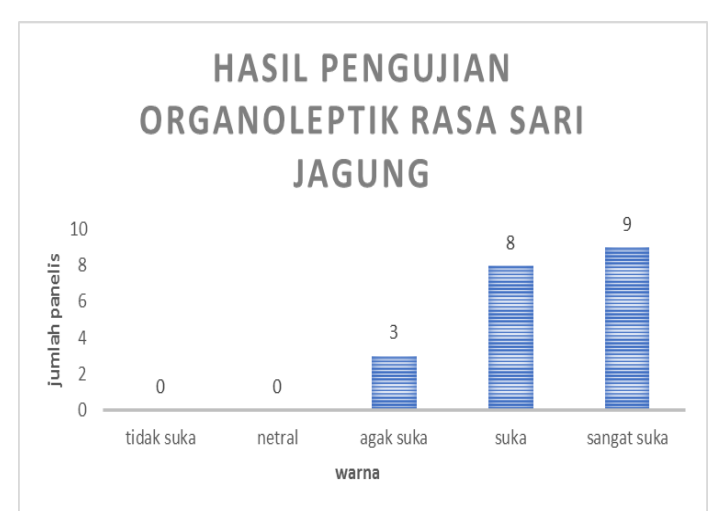

Grafik 4. Hasil data uji organoleptik dari rasa sari jagung.

Pada sari jagung ini mayoritas rasanya disukai oleh panelis dengan rerata 4,30.

\section{Tingkat Kemanisan}

Sari jagung memiliki cita rasa manis yang dihasilkan dari kandungan gula dalam jagung. Tinggi rendahnya gula pereduksi dari suatu produk dipengaruhi oleh jenis karbohidratnya namun juga dipengaruhi oleh aktifitas enzim pada masing-masing komoditas. Ujung dari suatu gula pereduksi adalah ujung yang mengandung gugus aldehida, semua monosakarida (glukosa, fruktosa dan galaktosa) dan disakarida (laktosa, maltosa), kecuali sukrosa dan pati (polisakarida), termasuk sebagai gula pereduksi (Setiawati \& Puspitojati, 2011).

Hasil uji organoleptik tingkat kemanisan sari jagung oleh panelis berbeda - beda, yaitu tingkat kemanisan yang sangat disukai, suka, agak suka, netral, dan tidak suka.

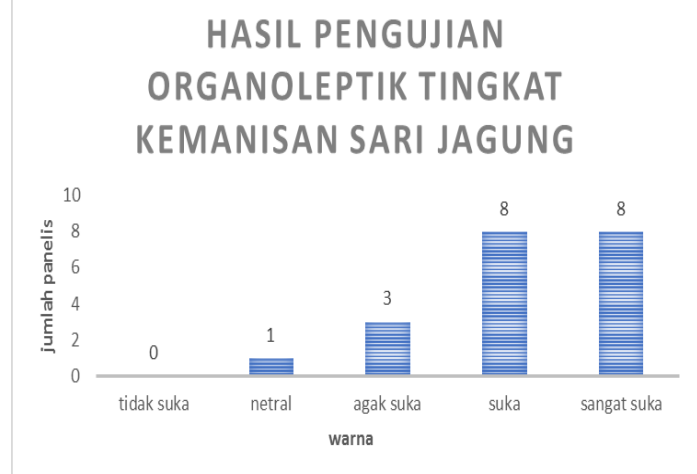

Grafik 5. Hasil data uji organoleptik dari tingkat kemanisan sari jagung. rerata 4,15 .

Pada sari jagung ini mayoritas tingkat kemanisannya disukai oleh panelis dengan

\section{Tingkat Kekentalan}

Tingkat kekentalan dari sari jagung yang dihasilkan adalah sedikit kental sampai agak kental. Sari jagung yang baik adalah sari jagung yang kekentalannya kompak, dimana tidak nampak adanya pemisahan antara padatan dan cairan.

Hasil uji organoleptik tingkat kekentalan sari jagung oleh panelis berbeda - beda, yaitu tingkat kekentalan yang sangat disukai, suka, agak suka, netral, dan tidak suka. 


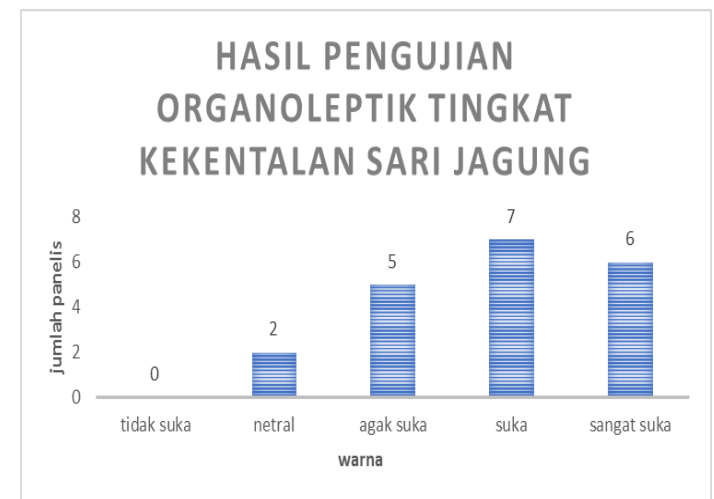

Grafik 6. Hasil data uji organoleptik dari tingkat kekentalan sari jagung.

Pada sari jagung ini mayoritas tingkat kekentalannya disukai oleh panelis dengan rerata 3,85.

\section{KESIMPULAN}

Dari hasil pengujian yang dilakukan didapatkan bahwa rata-rata semua penelis menyukai atau suka dengan warna, aroma, tekstur, rasa, tingkat kemanisan, dan tingkat kekentalan dari sari jagung yang di produksi oleh ATOMS. Minuman sari jagung yang diproduksi memiliki tekstur yang homogen, hal ini mengindikasikan bahwa protein yang terdapat pada produk tersebut tidak terdenaturasi.

\section{DAFTAR PUSTAKA}

Arikunto, S. (2010). Prosedur Penelitian. Jakarta: Rineka Cipta.

Harianja, C. H., Rusmalin, H., \& Yusraini, E. (2015). Pembuatan Susu Jagung dengan Pengayaan Kacang Hijau Bergerminasi dan Penambahan CMC sebagai Penstabil. Rekayasa Pangan Dan Pertanian, 3(1).

Ikawati, M. N. (2013). Pemanfaatan Sukun (Arthocarpus altilis) dan Susu Jagung (Zea mays) dalam pembuatan Es Krim dengan Penambahan CMC (Carboxy Methyl Cellulose). Naskah Publikasi. Universitas Muhammadiyah Surakarta.

Iskandar, D. (2011). Pengaruh Dosis Pupuk N, P, dan K Terhadap Pertumbuhan dan Produksi Tanaman Jagung Manis di Lahan Kering.

Jacobs, M. . (1980). The Chemistry and Technology of Food and Food Product. Interscience Publ. Co., New York, 1.

Muhajir, R., Rahim, A., \& Hutomo, G. S. (2014). Karakteristik Fisik dan Kimia Susu Jagung Manis pada Berbagai Lama Perebusan. Universitas Tadulako. Palu.

Nifah, K. U. (2015). Pengaruh Proporsi Tepung (Tapioka-Tempe) Dan Metode Pembuatan Adonan Terhadap Sifat Organoleptik Dan Fisik Kerupuk Tempe. E-Journal Boga, 4(3), 5764.

Prabandari, W. (2011). Pengaruh Penambahan Berbagai Jenis Bahan Penstabil Terhadap Karakteristik Fisikokimia dan Organoleptik Yoghurt Jagung. Fakultas Pertanian Universitas Sebelas Maret : Surakarta.

Setiawati, B., \& Puspitojati, E. (2011). Evaluasi Mutu Yoghurt Formulasi Susu Jagung Manis Kedelai. IImu-IImu Pertanian, 7, 14-23.

Suarni, S., \& Widowati, W. (2005). Struktur Komposisi dan Nutrisi Jagung. Balai Besar Penelitian Dan Pengembangan Pasca Panen Pertanian, Bogor.

Susilorini, T. E. (2006). Produk Olahan Susu. Jakarta: Penebar Swadaya. 
Suwarno, J. (2010). Uji Protein dan Organoleptik Pada Tempe dengan Bahan Dasar Jagung Manis. Universitas Muhammadiyah Surakarta: Surakarta.

Widyatmiko, E. D. S. (2008). Makalah Pengabdian Pada Masyarakat Aspek Ekonomi Wirausaha Susu jagung. Sleman, Yogyakarta. 